\title{
Model matematika penyebaran COVID-19 dengan penggunaan masker kesehatan dan karantina
}

Muhammad Manaqib, Irma Fauziah, and Eti Hartati

To cite this article:

M. Manaqib, I. Fauziah, and E. Hartati, "Model matematika penyebaran COVID-19 dengan penggunaan

masker kesehatan dan karantina", Jambura J. Biomath, vol. 2, no. 2, pp. 68-79, 2021

DOI: $h$ ttps://doi.org/10.34312/jjbm.v2i2.10483

(C) 2021 Author(s).

Articles You may be interested in

Analisis kestabilan dan kontrol optimal model matematika penyebaran penyakit Ebola dengan variabel kontrol berupa karantina

E. A. S. Megananda, C. Alfiniyah, and M. Miswanto http://dx.doi.org/10.34312/jibm.v2i1.10258

Parameters estimation of generalized Richards model for COVID-19 cases in Indonesia using genetic algorithm

M. Rayungsari, M. Aufin, and N. Imamah

http://dx.doi.org/10.34312/jjbm.v1i1.6910

Analisis dinamik model SVEIR pada penyebaran penyakit campak

S. O. S. P. Ahaya, E. Rahmi, and N. Nurwan

http://dx.doi.org/10.34312/jjbm.v1i2.8482

Estimasi Reproduction Number Model Matematika Penyebaran

Malaria di Sumba Tengah, Indonesia

E. M. Banni, M. A. Kleden, M. Lobo, and M. Z. Ndii

https://doi.org/10.34312/jjbm.v2i1.9971

Global stability of a fractional-order logistic growth model with

infectious disease

H. S. Panigoro and E. Rahmi

https://doi.org/10.34312/jjbm.v1i2.8135 


\title{
Model matematika penyebaran COVID-19 dengan penggunaan masker kesehatan dan karantina
}

\author{
Muhammad Manaqib ${ }^{1, *}$, Irma Fauziah ${ }^{2}$, Eti Hartati ${ }^{3}$ \\ 1,2,3 Program Studi Matematika, UIN Syarif Hidayatullah Jakarta, Tanggerang Selatan 15412, Indonesia \\ *Corresponding author. Email: muhammad.manaqib@uinjkt.ac.id
}

\begin{abstract}
Abstrak
Penelitian ini mengembangkan model penyebaran COVID-19 menggunakan model SIR yang ditambahkan penggunaan masker kesehatan dan karantina bagi individu terinfeksi. Populasi dibagi menjadi enam subpopulasi yaitu subpopulasi rentan tidak menggunakan masker kesehatan, rentan menggunakan masker kesehatan, terinfeksi tidak menggunakan masker kesehatan, terinfeksi menggunakan masker kesehatan, karantina bagu individu terinfeksi, dan subpopulasi sembuh. Hasilnya diperoleh dua titik ekuilibrium yaitu titik ekuilibrium bebas penyakit dan titik ekuilibrium endemik serta bilangan reproduksi dasar $\left(R_{0}\right)$. Eksistensi titik ekuilibrium bebas penyakit tanpa syarat, sedangakan titik ekulibrium endemik ada jika bilangan reproduksi dasar lebih dari satu. Analisis kestabilan titik ekuilibrium bebas penyakit stabil asimtotik lokal saat bilangan reproduksi dasar kurang dari satu. Selanjutnya dilakukan simulasi numerik untuk memberikan gambaran geometris terkait dengan hasil yang telah dianalisis. Hasilnya simulasi numerik mendukung hasil analisis yang diperoleh. Terakhir analisis sensitivitas bilangan reproduksi dasar yang dilakukan diperoleh empat parameter yang dominan berpengaruh terhadap bilangan reproduksi dasar yakni berturut-turut tingkat kontak individu rentan dengan terinfeksi, tingkat penggunaan masker kesehatan, tingkat pelepasan masker kesehatan, dan tingkat karantina bagi individu terinfeksi.
\end{abstract}

Kata Kunci: COVID-19; Masker Kesehatan; Model SIQR; Bilangan Reproduksi Dasar; Kestabilan Titik Ekulibrium

\begin{abstract}
This study developed a model for the spread of COVID-19 disease using the SIR model which was added by a health masks and quarantine for infected individuals. The population is divided into six subpopulations, namely the subpopulation susceptible without a health mask, susceptible using a health mask, infected without using a health mask, infected using a health mask, quarantine for infected individuals, and the subpopulation to recover. The results obtained two equilibrium points, namely the disease-free equilibrium point and the endemic equilibrium point and the basic reproduction number $\left(R_{0}\right)$. The existence of a disease-free equilibrium point is unconditional, whereas an endemic equilibrium point exists if the basic reproduction number is more than one. Stability analysis of the local asymptotically stable disease-free equilibrium point when the basic reproduction number is less than one. Furthermore, numerical simulations are carried out to provide a geometric picture related to the results that have been analyzed. The results of numerical simulations support the results of the analysis obtained. Finally, the sensitivity analysis of the basic reproduction numbers carried out obtained four parameters that dominantly affect the basic reproduction number, namely the rate of contact of susceptible individuals with infection, the rate of health mask use, the rate of health mask release, and the rate of quarantine for infected individuals.
\end{abstract}

Keywords: COVID-19; Health Mask; SIQR Model; Basic Reproduction Number; Stability of Equilibrium Point

\section{Pendahuluan}

Pada awal tahun 2020 dunia dihebohkan dengan adanya infeksi penyakit baru yang disebabkan oleh virus Corona, penyakit ini dinamakan Coronavirus Disease 2019 (COVID-19) [1]. Sebelumnya virus corona telah menimbulkan penyakit lebih serius seperti Severe Acute Respiratory Syndrom-Corona Virus (SARS-CoV) yang mewabah pada tahun 2003 dan Middle East Raspiratory Syndrom-Corona Virus (MESR-CoV) mewabah pada tahun $2012[2,3]$. COVID-19 adalah penyakit sindrom pernafasan yang disebabkan oleh salah satu jenis corona virus SARS-CoV-2. COVID-19 dapat menimbulkan gejala ringan, sedang atau berat, gejala klinis utama yang muncul yaitu demam, batuk dan kesulitan bernapas [4]. Secara umum penularan virus ini terjadi melalui droplet atau cairan tubuh yang terpercik pada seseorang atau benda-benda disekitar yang berjarak 1-2 meter melalui batuk dan bersin [5-7]. World Health Organization (WHO) menyampaikan bahwa wabah COVID-19 pertama kali dilaporkan di Wuhan China, pada 31 Desember 2019 [8]. Selanjutnya pada tanggal 11 Maret 2020 WHO mengumumkan COVID-19 telah menginveksi lebih dari 118.000 orang, menyebar di 114 negara dan mengakibatkan 4.291 orang meninggal. Atas dasar tersebut WHO menetapkan COVID-19 sebagai pandemi global yang artinya COVID-19 telah menyebar luas di seluruh dunia [9].

Indonesia mengkonfirmasi kasus pertama COVID-19 pada tanggal 02 maret 2020, ada dua orang warga Indonesia positif terjangkit virus COVID-19 yang diduga tertular dari warga negara Jepang. Penambahan 
jumlah kasus COVID-19 di Indonesia pun terus bertambah hingga mencapai satu juta kasus pada tanggal 26 Januari 2021 atau 11 bulan sejak konfirmasi kasus pertama COVID-19 di Indonesia. Hingga 11 Mei 2021 tercatat 1.718.575 kasus terkonfirmasi positif, 1.574 .615 sembuh dan 47.218 menginggal dunia [10]. Upaya pengendalian penyebaran COVID-19 di Indonesia adalah dengan menerapkan kebijakan protol kesehatan yakni 3M (Memakai Masker, Mencuci Tangan, Menjaga Jarak) [11]. Selain itu Pemerintah Indonesia juga memberlakukan kebijakan karantina atau isolasi pasien penderita COVID-19, bagi pasien dengan resiko tinggi dikarantina rumah sakit sedangkan pasien tanpa gejala dikarantina di tempat-tempat yang disediakan pemerintah atau karantina mandiri. Pasien COVID-19 diisolasi supaya tidak melakukan kontak terhadap masyarakat sekitar sehingga diharapkan tidak menularkan kepada orang lain sampai dinyatakan sembuh.

Pemodelan matematika merupakan salah satu pendekatan yang dapat digunakan untuk menjelaskan permasalahan yang terjadi dalam dunia nyata dan mencari penyelesaiannya $[3,12]$. Sehingga penelitian terkait pemodelan matematika COVID-19 mulai banyak dikembangkan sejak pandemi terjadi pada awal tahun 2020. Model dasar epidemi penyakit SIR (susceptible, infectious, removed) yang dikenalkan oleh Kermack \& McKendrick [13] diaplikasikan kedalam COVID-19 diantaranya oleh Fosu et al.[14], Imran et al. [15], Ivanova \& Dospatliev [16], Liao et al. [17], dan Mitra [18]. Selanjutnya model dikembangkan dengan penambahan kompartemen individu dikarantina diantaranya oleh Amaku et al. [19], Chinazzi et al. [20], Tang et al. [21], dan Xiang et al. [22]. Pemodelan matematika epidemi penyakit dengan menambahkan penggunaan masker kesehatan sebelumnya telah dilakukan pada penyakit pernapasan seperti MERS-Cov [3, 23] dan penyakit Pulmonary Tuberculosis (TBC) [24]. Sehingga pemodelan matematika epidemi penyakit dengan menambahkan penggunaan masker kesehatan juga dapat diaplikasikan kedalam COVID-19.

Dalam penelitian ini akan dikembangkan model matematika penyebaran COVID-19 SIR dengan dengan menambahkan penggunaan masker kesehatan dan karantina. Subpopulasi rentan $(S)$ dibagi menjadi dua subpopulasi yaitu subpopulasi rentan tidak menggunakan masker kesehatan $\left(S_{1}\right)$ dan subpopulasi rentan menggunakan masker kesehatan $\left(S_{2}\right)$ dan subpopulasi terinfeksi $(I)$ dibagi menjadi dua subpopulasi terinfeksi yaitu subpopulasi individu terinfeksi tidak menggunakan masker kesehatan $\left(I_{1}\right)$ dan subpopulasi terinfeksi menggunakan masker kesehatan $\left(I_{2}\right)$. Model yang diperoleh selanjutnya dianalisis kestabilan titik ekulibriumnya. Setelah itu akan dilakukan simulasi model untuk memberikan gambaran geometris dari solusi dan untuk mendukung teorema yang diperoleh. Terakhir dilakukan analisis sensitifitas parameter-parameter model terhadap bilangan reproduksi awal untuk mengetahui parameter yang dominan berpengaruh terhadap penyebaran COVID-19.

\section{Formulasi Model}

Model matematika dalam penelitian ini membagi populasi individu menjadi enam subpopulasi yaitu subpopulasi individu rentan tidak menggunakan masker kesehatan $\left(S_{1}\right)$, individu rentan menggunakan masker kesehatn $\left(S_{2}\right)$, subpopulasi individu terinfeksi tidak menggunkan masker kesehatan $\left(I_{1}\right)$, individu terinfeksi menggunakan masker kesehatan $\left(I_{2}\right)$, karantina $(Q)$, dan sembuh $(R)$. Asumsi yang digunakan dalam penelitian ini adalah sebagai berikut.

1. Penyakit diasumsikan fatal.

2. Virus yang menyebabkan COVID-19 adalah virus corona.

3. Populasi diasumsikan tertutup, artinya tidak ada individu masuk kedalam populasi atau keluar dari populasi (tidak ada migrasi).

4. Tingkat kelahiran dan kematian alami diasumsikan sama.

5. Populasi diasumsikan bercampuran homogen.

6. Individu rentan dengan menggunakan masker kesehatan $\left(S_{2}\right)$ tidak dapat tertular oleh virus.

7. Individu rentan dengan meggunakan masker kesehatan $\left(S_{2}\right)$ akan kembali ke komparteman rentan tidak menggunakan masker kesehatan $\left(S_{1}\right)$ jika berhenti menggunakan masker kesehatan.

8. Individu terinfeksi dengan meggunakan masker kesehatan $\left(I_{2}\right)$ akan kembali ke komparteman infeksi tidak menggunakan masker kesehatan $\left(I_{1}\right)$ jika berhenti menggunakan masker kesehatan.

9. COVID-19 menular melalui kontak langsung dengan individu terinfeksi virus corona.

10. Setiap individu yang terinfeksi pasti akan melalui proses karantina.

11. Individu yang terinfeksi dan dikarantina dapat meninggal akibat penyakit.

12. Individu yang dikarantina dapat sembuh dari penyakit.

13. Individu yang sembuh memiliki kekebalan.

Variabel dan parameter yang digunakan dalam model penyebaran COVID-19 dengan penggunaan masker kesehatan dan karantina disajikan dalam Tabel 1 dan Tabel 2. 
Tabel 1. Daftar variabel model penyebaran COVID-19 dengan penggunaan masker kesehatan dan karantina

\begin{tabular}{|c|c|c|c|c|}
\hline No. & Variabel & Definisi & Syarat & Satuan \\
\hline 1 & $N(t)$ & Jumlah populasi individu pada waktu ke-t & $N(t) \geq 0$ & Individu \\
\hline 2 & $S_{1}(t)$ & $\begin{array}{l}\text { Jumlah individu rentan terinfeksi tidak menggunakan masker kesehatan } \\
\text { pada waktu ke-t }\end{array}$ & $S_{1}(t) \geq 0$ & Individu \\
\hline 3 & $S_{2}(t)$ & $\begin{array}{l}\text { Jumlah individu rentan terinfeksi menggunakan masker kesehatan pada } \\
\text { waktu ke-t }\end{array}$ & $S_{2}(t) \geq 0$ & Individu \\
\hline 4 & $I_{1}(t)$ & $\begin{array}{l}\text { jumlah individu terinfeksi tidak menggunakan masker kesehatan pada } \\
\text { waktu ke-t }\end{array}$ & $I_{1}(t) \geq 0$ & Individu \\
\hline 5 & $I_{2}(t)$ & $\begin{array}{l}\text { jumlah individu terinfeksi menggunakan masker kesehatan pada waktu ke- } \\
\mathrm{t}\end{array}$ & $I_{2}(t) \geq 0$ & Individu \\
\hline 6 & $Q(t)$ & jumlah individu yang dikarantina pada waktu ke-t & $Q(t) \geq 0$ & Individu \\
\hline 7 & $D(t)$ & $\begin{array}{l}\text { jumlah individu meninggal yang diakibatkan oleh penyakit pada waktu ke- } \\
\mathrm{t}\end{array}$ & $D(t) \geq 0$ & Individu \\
\hline 8 & $R(t)$ & jumlah individu sembuh dari penyakit pada waktu ke- $t$ & $R(t) \geq 0$ & Individu \\
\hline
\end{tabular}

Tabel 2. Daftar parameter model penyebaran COVID-19 dengan penggunaan masker kesehatan dan karantina

\begin{tabular}{cclc}
\hline No. & Parameter & Definisi & Syarat \\
\hline 1 & $\mu$ & Tingakt kelahiran dan kematian alami populasi individu & $\mu \geq 0$ \\
2 & $u_{1}$ & Tingkat penggunaan masker kesehatan & $u_{1} \geq 0$ \\
3 & $u_{2}$ & Tingkat pelepasan masker kesehatan & $u_{2} \geq 0$ \\
4 & $\beta$ & Tingkat individu rentan menjadi individu terinfeksi & $\beta \geq 0$ \\
5 & $\alpha$ & Tingkat individu yang dikarantina & Perindividu perhari \\
6 & $\gamma$ & Tingkat kematian yang diakibatkan oleh penyakit & $\alpha \geq 0$ \\
7 & $\theta$ & Tingakat kesembuhan tiap individu & $\gamma \geq 0$ \\
\hline
\end{tabular}

Secara skematis proses penyebaran COVID-19 dengan penggunaan masker kesehatan dan karantina adalah sebagai berikut.

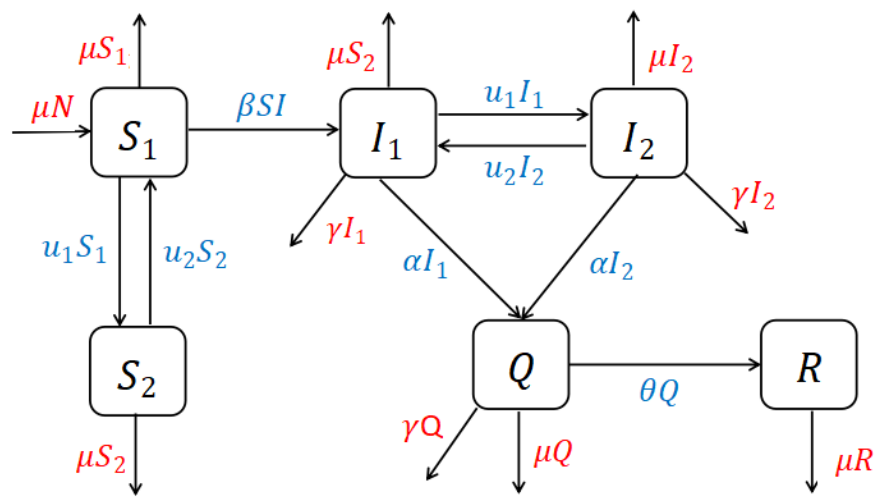

Gambar 1. Diagram transfer model matematika penyebaran COVID-19 dengan penggunaan masker kesehatan dan karantina

Berdasarkan penjelasan di atas, maka penyebaran COVID-19 dengan penggunaan masker kesehatan dan karantina dapat dimodelkan menjadi sistem persamaan diferensial biasa nonlinear sebagai berikut.

$$
\begin{aligned}
\frac{d S_{1}}{d t} & =\mu N+u_{2} S_{2}-S_{1}\left(\mu+u_{1}\right)-\beta S_{1} I_{1} \\
\frac{d S_{2}}{d t} & =u_{1} S_{1}-S_{2}\left(\mu+u_{2}\right) \\
\frac{d I_{1}}{d t} & =\beta S_{1} I_{1}+u_{2} I_{2}-I_{1}\left(\mu+u_{1}+\alpha+\gamma\right) \\
\frac{d I_{2}}{d t} & =u_{1} I_{1}-I_{2}\left(\mu+u_{2}+\alpha+\gamma\right) \\
\frac{d Q}{d t} & =\alpha\left(I_{1}+I_{2}\right)-Q(\mu+\gamma+\theta) \\
\frac{d R}{d t} & =\theta Q-\mu R
\end{aligned}
$$


dengan nilai $N=S_{1}+S_{2}+I_{1}+I_{2}+Q+R$ maka

$$
\begin{aligned}
\frac{d N}{d t} & =\mu N-\mu S_{1}-\mu S_{2}-\mu I_{1}-\mu I_{2}-\mu Q-\mu R-\gamma I_{1}-\gamma I_{2}-\gamma Q \\
& =\mu N-\mu\left(S_{1}+S_{2}+I_{1}+I_{2}+Q+R\right)-\gamma I_{1}-\gamma I_{2}-\gamma Q \leq 0,
\end{aligned}
$$

sehingga $N(t) \leq k$ untuk $k$ bilangan bulat positif. Jika digunakan satuan proporsi terhadap jumlah populasi awal maka $N(t) \leq 1$. Selanjutnya didefiniskan daerah invarian positif yang memenuhi sistem (1) yaitu

$$
\Omega=\left\{\left(S_{1}, S_{2}, I_{1}, I_{2}, Q_{1}, R\right) \in \Re_{+}^{6}: 0 \leq N \leq 1\right\} .
$$

adalah himpunan tertutup domain dari sistem (1).

Diperhatikan bahwa kompartemen $R$ tidak mempengaruhi laju perubahan jumlah individu pada kompartemen yang lain, maka dalam analisis model yang dilakukan persamaan $R$ untuk sementara dapat diabaikan dari sistem. Sehingga sistem (1) dapat ditulis sebagai berikut.

$$
\begin{aligned}
\frac{d S_{1}}{d t} & =N+u_{2} S_{2}-S_{1}\left(+u_{1}\right)-S_{1} I_{1} \\
\frac{d S_{2}}{d t} & =u_{1} S_{1}-S_{2}\left(+u_{2}\right) \\
\frac{d I_{1}}{d t} & =\beta S_{1} I_{1}+u_{2} I_{2}-I_{1}\left(+u_{1}+a+\gamma\right) \\
\frac{d I_{2}}{d t} & =u_{1} I_{1}-I_{2}\left(+u_{2}+a+\gamma\right) \\
\frac{d Q}{d t} & =a\left(I_{1}+I_{2}\right)-Q(+\gamma+\theta) .
\end{aligned}
$$

\section{Hasil dan Pembahasan}

\subsection{Titik Ekulibrium dan Bilangan Reproduksi Dasar}

Analisa model dilakukan dengan menganalisis kestabilan titik ekuilibrium model. Titik ekuilibrium diperoleh dengan cara membuat persamaan pada sistem (2) sama dengan nol sebagai berikut.

$$
\begin{aligned}
\mu N+u_{2} S_{2}-S_{1}\left(\mu+u_{1}\right)-\beta S_{1} I_{1} & =0 \\
u_{1} S_{1}-S_{2}\left(\mu+u_{2}\right) & =0 \\
\beta S_{1} I_{1}+u_{2} I_{2}-I_{1}\left(\mu+u_{1}+\alpha+\gamma\right) & =0 \\
u_{1} I_{1}-I_{2}\left(\mu+u_{2}+\alpha+\gamma\right) & =0 \\
\alpha\left(I_{1}+I_{2}\right)-Q(\mu+\gamma+\theta) & =0
\end{aligned}
$$

Titik ekuilibrium bebas penyakit adalah titik ekuilibrium pada saat tidak ada penyakit dalam populasi. Terpenuhinya keadaan bebas penyakit adalah tidak ada satu individupun yang terinfeksi penyakit, sehingga $I_{1}=I_{2}=0$. Dengan mensubstitusikan $I_{1}=I_{2}=0$ ke pers. (3) diperoleh titik ekuilibrium bebas penyakit $E_{1}\left(S_{1}, S_{2}, I_{1}, I_{2}, Q\right)=\left(\frac{\mu+u_{2}}{\mu+u_{1}+u_{2}}, \frac{u_{1}}{\mu+u_{1}+u_{2}}, 0,0,0\right)$.

Selanjutnya akan dicari titik ekuilibrium endemik yaitu titik ekuilibium saat kelas terinfeksi tidak nol atau saat penyakit menyebar dalam populasi. Endemik penyakit artinya di dalam populasi selalu terdapat individu yang terserang penyakit, sehingga diperoleh $I$ pada titik ekuilibrium endemik penyakit yaitu $I_{1}>0$ dan $I_{2}>0$. Diperoleh titik ekuilibrium endemik sistem 3 adalah $E_{2}\left(S_{1}^{*}, S_{2}^{*}, I_{1}^{*}, I_{2}^{*}, Q^{*}\right)$

$$
\begin{aligned}
& S_{1}^{*}=\frac{(\mu+\alpha+\gamma)\left(\mu+\alpha+\gamma+u_{1}+u_{2}\right)}{\beta\left(\mu+\alpha+\gamma+u_{2}\right)}, \\
& S_{2}^{*}=\frac{u_{1}(\mu+\alpha+\gamma)\left(\mu+\alpha+\gamma+u_{1}+u_{2}\right)}{\beta\left(\mu+\alpha+\gamma+u_{2}\right)\left(\mu+u_{2}\right)}, \\
& I_{1}^{*}=\frac{\mu\left(\beta\left(\mu+u_{2}\right)\left(\mu+\alpha+\gamma+u_{2}\right)-\left(\mu+u_{1}+u_{2}\right)(\mu+\alpha+\gamma)\left(\mu+\alpha+\gamma+u_{1}+u_{2}\right)\right)}{\beta\left(\mu+u_{2}\right)\left(\mu+\alpha+\gamma+u_{2}\right)\left(\mu+\alpha+\gamma+u_{1}+u_{2}\right)}, \\
& I_{2}^{*}=\frac{u_{1} I_{1}^{*}}{\left(\mu+\alpha+\gamma+u_{2}\right)}, Q^{*}=\frac{\alpha I_{1}^{*}\left(\mu+\alpha+\gamma+u_{1}+u_{2}\right)}{\left(\mu+\alpha+\gamma+u_{2}\right)(\mu+\gamma+\theta)} .
\end{aligned}
$$


Selanjutnya akan ditentukan bilangan reproduksi dasar menggunakan matriks generasi berikutnya (next generation matrices). Penentuan bilangan reproduksi awal sistem (2) dengan cara sebagai berikut.

1. Lakukan pelinieran terhadap subsistem terinfeksi pada titik ekuilibrium bebas penyakit.

$$
\begin{aligned}
J & =\left[\begin{array}{lll}
\frac{\partial\left(\frac{d I_{1}}{d t}\right)}{\partial I_{1}} & \frac{\partial\left(\frac{d I_{1}}{d t}\right)}{\partial I_{2}} & \frac{\partial\left(\frac{d I_{1}}{d t}\right)}{\partial Q} \\
\frac{\partial\left(\frac{d I_{2}}{d t}\right)}{\partial I_{1}} & \frac{\partial\left(\frac{d I_{2}}{d t}\right)}{\partial I_{2}} & \frac{\partial\left(\frac{d I_{2}}{d t}\right)}{\partial Q} \\
\frac{\partial\left(\frac{d Q}{d t}\right)}{\partial I_{1}} & \frac{\partial\left(\frac{d Q}{d t}\right)}{\partial I_{2}} & \frac{\partial\left(\frac{d Q}{d t}\right)}{\partial Q}
\end{array}\right] \\
= & {\left[\begin{array}{ccc}
\beta s_{1}-\left(\mu+u_{1}+\alpha+\gamma\right) & u_{2} & 0 \\
u_{1} & -\left(\mu+u_{2}+\alpha+\gamma\right) & 0 \\
\alpha & \alpha & -(\mu+\gamma+\theta)
\end{array}\right] } \\
J_{\left(s_{1}, s_{2}, i_{1}, i_{2}, q, d\right)} & =\left[\begin{array}{ccc}
\beta\left(\frac{\mu+u_{2}}{\mu+u_{1}+u_{2}}\right)-\left(\mu+u_{1}+\alpha+\gamma\right) & 0 \\
u_{1} & -\left(\mu+u_{2}+\alpha+\gamma\right) & 0 \\
\alpha & \alpha
\end{array}\right]
\end{aligned}
$$

2. Dekomposisi matriks jacobi $(\boldsymbol{J})$ menjadi $\boldsymbol{J}=\boldsymbol{F}-\boldsymbol{V}$, dengan $\boldsymbol{F}$ matriks transmisi dan $\boldsymbol{V}$ matriks transisi

$$
\boldsymbol{F}=\left[\begin{array}{ccc}
\beta\left(\frac{\mu+u_{2}}{\mu+u_{1}+u_{2}}\right) & 0 & 0 \\
0 & 0 & 0 \\
0 & 0 & 0
\end{array}\right], \boldsymbol{V}=\left[\begin{array}{ccc}
\left(\mu+u_{1}+\alpha+\gamma\right) & -u_{2} & 0 \\
-u_{1} & \left(\mu+u_{2}+\alpha+\gamma\right) & 0 \\
-\alpha & -\alpha & (\mu+\gamma+\theta)
\end{array}\right]
$$

Hitung $V^{-1}$

$$
\boldsymbol{V}^{-1}=\left[\begin{array}{ccc}
\frac{\left(\mu+u_{2}+\alpha+\gamma\right)}{A} & \frac{u_{2}}{A} & 0 \\
\frac{u_{1}}{A} & \frac{\left(\mu+u_{1}+\alpha+\gamma\right)}{A} & 0 \\
\frac{u_{1} \alpha+\alpha\left(\mu+u_{2}+\alpha+\gamma\right)}{A(\mu+\gamma+\theta)} & \frac{\alpha\left(\mu+u_{1}+\alpha+\gamma\right)+u_{2} \alpha}{A(\mu+\gamma+\theta)} & \frac{1}{(\mu+\gamma+\theta)}
\end{array}\right]
$$

dengan $A=(\mu+\alpha+\gamma)\left(\mu+u_{1}+u_{2}+\alpha+\gamma\right)$.

3. Hitung $R_{0}$ dengan $R_{0}=\rho\left(\boldsymbol{F} \boldsymbol{V}^{-1}\right)$

$$
\begin{aligned}
& F V^{-1}=\left[\begin{array}{ccc}
\beta\left(\frac{\mu+u_{2}}{\mu+u_{1}+u_{2}}\right) & 0 & 0 \\
0 & 0 & 0 \\
0 & 0 & 0
\end{array}\right]\left[\begin{array}{ccc}
\frac{\left(\mu+u_{2}+\alpha+\gamma\right)}{A} & \frac{u_{2}}{A} & 0 \\
\frac{u_{1}}{A} & \frac{\left(\mu+u_{1}+\alpha+\gamma\right)}{A} & 0 \\
\frac{u_{1} \alpha+\alpha\left(\mu+u_{2}+\alpha+\gamma\right)}{A(\mu+\gamma+\theta)} & \frac{\alpha\left(\mu+u_{1}+\alpha+\gamma\right)+u_{2} \alpha}{A(\mu+\gamma+\theta)} & \frac{1}{(\mu+\gamma+\theta)}
\end{array}\right] \\
& =\left[\begin{array}{ccc}
\beta\left(\frac{\mu+u_{2}}{\mu+u_{1}+u_{2}}\right) \frac{\mu+u_{2}+\alpha+\gamma}{A} & \beta\left(\frac{\mu+u_{2}}{\mu+u_{1}+u_{2}}\right) \frac{u_{2}}{A} & 0 \\
0 & 0 & 0 \\
0 & 0 & 0
\end{array}\right]
\end{aligned}
$$

Nilai eigen matriks $\left(\boldsymbol{F} \boldsymbol{V}^{-1}\right)$ diperoleh dari persamaan berikut

$$
\begin{aligned}
& \operatorname{det}\left|\lambda \boldsymbol{I}-\boldsymbol{F V}^{-1}\right|=0 \\
\Leftrightarrow & {\left[\begin{array}{ccc}
\lambda-\beta\left(\frac{\mu+u_{2}}{\mu+u_{1}+u_{2}}\right) \frac{\mu+u_{2}+\alpha+\gamma}{A} & \beta\left(\frac{\mu+u_{2}}{\mu+u_{1}+u_{2}}\right) \frac{u_{2}}{A} & 0 \\
0 & \lambda & 0 \\
0 & 0 & \lambda
\end{array}\right]=0 } \\
\Leftrightarrow & \left(\lambda-\beta\left(\frac{\mu+u_{2}}{\mu+u_{1}+u_{2}}\right) \frac{\mu+u_{2}+\alpha+\gamma}{A}\right) \lambda^{2}=0
\end{aligned}
$$

Sehingga diperoleh $\lambda_{1,2}=0$ dan

$$
\lambda_{3}=\beta\left(\frac{\mu+u_{2}}{\mu+u_{1}+u_{2}}\right) \frac{\mu+u_{2}+\alpha+\gamma}{A} .
$$

Karena bilangan reproduksi dasar diperoleh dari radius spektral atau dari nilai eigen terbesar, maka diperoleh

$$
R_{0}=\frac{\beta\left(\mu+u_{2}\right)\left(\mu+u_{2}+\alpha+\gamma\right)}{\left(\mu+u_{1}+u_{2}\right)(\mu+\alpha+\gamma)\left(\mu+u_{1}+u_{2}+\alpha+\gamma\right)}
$$




\section{Teorema 1. (Eksistensi titik ekuilibrium)}

(i) Jika $R_{0}<1$ maka sistem (2) hanya memiliki satu titik ekuilibrium, yaitu titik ekuilibrium bebas penyakit $E_{1}$.

(ii) Jika $R_{0}>1$ maka sistem (2) hanya memiliki dua titik ekuilibrium, yaitu titik ekuilibrium bebas penyakit $E_{1}$ dan titik ekuilibrium endemik $E_{2}$.

bukti. Untuk membuktikan teorema 1 perlu ditunjukkan jika $R_{0}>1$ maka titik ekuilibrium $E_{2}$ ada. Eksistensi suatu titik ekuilibrium ditunjukkan dengan setiap elemennya positif sesuai syarat pembentukan model ini. Perhatikan $E_{2}\left(S_{1}^{*}, S_{2}^{*}, I_{1}^{*}, I_{2}^{*}, Q^{*}\right)$ pada persamaan (4), karena semua parameter yang digunakan dalam pemodelan ini positif maka jelas $S_{1}^{*}, S_{2}^{*}$, dan $Q^{*}$ positif. Sedangkan $I_{2}^{*}$ positif jika $I_{1}^{*}$ positif, sehingga untuk menunjukkan semua elemen $E_{2}\left(S_{1}^{*}, S_{2}^{*}, I_{1}^{*}, I_{2}^{*}, Q^{*}\right)$ positif cukup ditunjukkan $I_{1}^{*}$.

$$
\begin{aligned}
I_{1}^{*}= & \frac{\mu\left(\beta\left(\mu+u_{2}\right)\left(\mu+\alpha+\gamma+u_{2}\right)-\left(\mu+u_{1}+u_{2}\right)(\mu+\alpha+\gamma)\left(\mu+\alpha+\gamma+u_{1}+u_{2}\right)\right)}{\beta\left(\mu+u_{2}\right)\left(\mu+\alpha+\gamma+u_{2}\right)\left(\mu+\alpha+\gamma+u_{1}+u_{2}\right)} \\
= & \frac{\mu}{\beta\left(\mu+u_{2}\right)\left(\mu+\alpha+\gamma+u_{2}\right)\left(\mu+\alpha+\gamma+u_{1}+u_{2}\right)} \\
& \left(\beta\left(\mu+u_{2}\right)\left(\mu+\alpha+\gamma+u_{2}\right)-\left(\mu+u_{1}+u_{2}\right)(\mu+\alpha+\gamma)\left(\mu+\alpha+\gamma+u_{1}+u_{2}\right)\right) \\
= & \frac{\mu}{\beta\left(\mu+u_{2}\right)\left(\mu+\alpha+\gamma+u_{2}\right)\left(\mu+\alpha+\gamma+u_{1}+u_{2}\right)} \times \frac{\left(\mu+u_{1}+u_{2}\right)(\mu+\alpha+\gamma)\left(\mu+\alpha+\gamma+u_{1}+u_{2}\right)}{\left(\mu+u_{1}+u_{2}\right)(\mu+\alpha+\gamma)\left(\mu+\alpha+\gamma+u_{1}+u_{2}\right)} \\
& \left(\beta\left(\mu+u_{2}\right)\left(\mu+\alpha+\gamma+u_{2}\right)-\left(\mu+u_{1}+u_{2}\right)(\mu+\alpha+\gamma)\left(\mu+\alpha+\gamma+u_{1}+u_{2}\right)\right) \\
= & \frac{\mu\left(\mu+u_{1}+u_{2}\right)(\mu+\alpha+\gamma)}{\beta\left(\mu+u_{2}\right)\left(\mu+\alpha+\gamma+u_{2}\right)}\left(\frac{\beta\left(\mu+u_{2}\right)\left(\mu+\alpha+\gamma+u_{2}\right)}{\left(\mu+u_{2}\right)\left(\mu+\alpha+\gamma+u_{2}\right)\left(\mu+\alpha+\gamma+u_{1}+u_{2}\right)}-1\right) \\
= & \frac{\mu\left(\mu+u_{1}+u_{2}\right)(\mu+\alpha+\gamma)}{\beta\left(\mu+u_{2}\right)\left(\mu+\alpha+\gamma+u_{2}\right)}\left(R_{0}-1\right) .
\end{aligned}
$$

Berdasarkan pers. (6), karena $R_{0}>1$ maka $I_{1}^{*}>0$.

\subsection{Kestabilan Titik Ekuilibrium}

Model matematika penyebaran COVID-19 pada sistem (2) merupakan sistem nonlinear. Analisis perilaku model dilakukan dengan terlebih dahulu membentuk matriks Jacobian hasil linearisasi sistem (2) disekitar titik ekuilibrium. Matriks Jacobian hasil linearisasi model penyebaran COVID-19 disekitar titik ekuilibrium bebas penyakit $E_{1}\left(S_{1}, S_{2}, I_{1}, I_{2}, Q\right)$ adalah sebagai berikut.

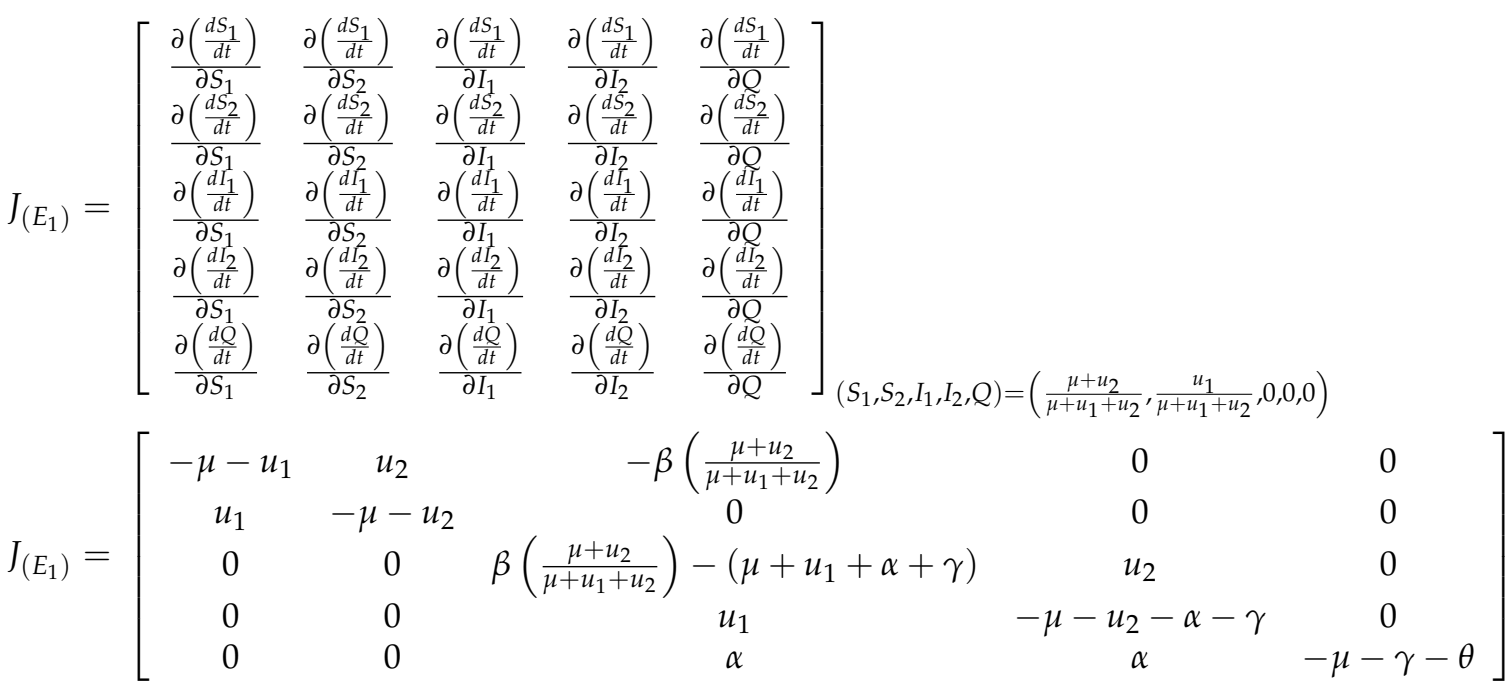

Teorema 2. $R_{0}<1$ maka titik ekuilibrium bebas penyakit $E_{1}$ sistem (2) stabil asimtotik lokal.

bukti. Nilai eigen matriks Jacobi dari sistem (4) pada titik ekuilibrium bebas penyakit $E_{1}$ diperoleh dari persaman berikut.

$$
\operatorname{det}\left(\lambda I-J_{\left(E_{1}\right)}\right)=0
$$




$$
\begin{aligned}
& \left|\begin{array}{ccccc}
\lambda+\mu+u_{1} & -u_{2} & \beta\left(\frac{\mu+u_{2}}{\mu+u_{1}+u_{2}}\right) & 0 & 0 \\
-u_{1} & \lambda+\mu+u_{2} & 0 & 0 & 0 \\
0 & 0 & \lambda-\beta\left(\frac{\mu+u_{2}}{\mu+u_{1}+u_{2}}\right)+\left(\mu+u_{1}+\alpha+\gamma\right) & -u_{2} & 0 \\
0 & 0 & -u_{1} & \lambda+\mu+u_{2}+\alpha+\gamma & 0 \\
0 & 0 & -\alpha & -\alpha & \lambda+\mu+\gamma+\theta
\end{array}\right|=0 \\
& \Leftrightarrow(\lambda+\mu+\gamma+\theta)\left(\left(\lambda+\mu+u_{1}\right)\left(\lambda+\mu+u_{2}\right)-u_{1} u_{2}\right)\left((\lambda+m)\left(\lambda+\mu+u_{2}+\alpha+\gamma\right)-u_{1} u_{2}\right)=0, \\
& \text { dengan } m=\left(\mu+u_{1}+\alpha+\gamma\right)-\beta\left(\frac{\mu+u_{2}}{\mu+u_{1}+u_{2}}\right) \\
& \Leftrightarrow(\lambda+\mu+\gamma+\theta) P Q=0 \\
& P=\left(\lambda+\mu+u_{1}\right)\left(\lambda+\mu+u_{2}\right)-u_{1} u_{2} \\
& =\lambda^{2}+\lambda\left(2 \mu+u_{1}+u_{2}\right)+\left(\mu^{2}+\mu u_{2}+\mu u_{1}\right) \\
& Q=(\lambda+m)\left(\lambda+\mu+u_{2}+\alpha+\gamma\right)-u_{1} u_{2} \\
& =\lambda^{2}+\lambda\left(\mu+u_{2}+\alpha+\gamma+m\right)+m\left(\mu+u_{2}+\alpha+\gamma\right)-u_{1} u_{2} .
\end{aligned}
$$

Maka diperoleh persamaan karakteristik untuk $J_{\left(E_{1}\right)}$ adalah

$$
(\lambda+\mu+\gamma+\theta) P Q=0
$$

dengan

$$
\begin{aligned}
& P=\lambda^{2}+\lambda\left(2 \mu+u_{1}+u_{2}\right)+\left(\mu^{2}+\mu u_{2}+\mu u_{1}\right) \\
& Q=\lambda^{2}+\lambda\left(\mu+u_{2}+\alpha+\gamma+m\right)+m\left(\mu+u_{2}+\alpha+\gamma\right)-u_{1} u_{2}
\end{aligned}
$$

Berdasarkan persamaan karakteristik (7) diperoleh $\lambda_{1}=-\mu-\gamma-\theta$, karena $\mu, \gamma$, dan $\theta$ bernilai positif maka bagian real dari nilai eigen pertama tersebut adalah negatif. Selanjutnya tanda dari bagian real nilai eigen $\lambda_{2}, \lambda_{3}, \lambda_{4}$, dan $\lambda_{5}$ dianalisis dengan kriteria Routh-Hurwitz. Berdasarkan pers. (8) diperoleh

$$
a_{0}=1, a_{1}=2 \mu+u_{1}+u_{2}, a_{2}=\mu^{2}+\mu u_{2}+\mu u_{1} .
$$

Karena $\mu, u_{1}$, dan $u_{1}$ positif maka $a_{0}>0, a_{1}>0$, dan $a_{2}>0$. Selanjutnya matriks Routh Hurwitz $\Delta_{1}=a_{1}>0$ dan $\Delta_{2}=\left|\begin{array}{cc}a_{1} & a_{0} \\ 0 & a_{2}\end{array}\right|=a_{1} a_{2}$ karena $a_{1}>0$ dan $a_{2}>0$ maka $\Delta_{2}$. Sehingga dapat disimpulkan polinomial $P$ memenuhi kriteria Routh Hurwitz, maka bagian real akar-akar polinomial $P$ bernilai negatif atau dapat dituliskan $\operatorname{Re}\left(\lambda_{2}\right)<0$ dan $\operatorname{Re}\left(\lambda_{3}\right)<0$.

Selanjutnya berdasarkan pers. (9) diperoleh

$$
a_{0}=1, a_{1}=\mu+u_{2}+\alpha+\gamma+m, a_{2}=m\left(\mu+u_{2}+\alpha+\gamma\right)-u_{1} u_{2} .
$$

Diperhatikan bahwa

$$
\begin{aligned}
a_{1} & =\mu+u_{2}+\alpha+\gamma+m \\
& =\left(2 \mu+u_{1}+u_{2}+2 \alpha+2 \gamma\right)-\beta\left(\frac{\mu+u_{2}}{\mu+u_{1}+u_{2}}\right) \\
& =\frac{\left(2 \mu+u_{1}+u_{2}+2 \alpha+2 \gamma\right)-\beta\left(\mu+u_{2}\right)}{\mu+u_{1}+u_{2}}
\end{aligned}
$$

dan diketahui $R_{0}<1$ maka

$$
\begin{aligned}
\beta\left(\mu+u_{2}\right)\left(\mu+\alpha+\gamma+u_{2}\right) & <\left(\mu+u_{1}+u_{2}\right)(\mu+\alpha+\gamma)\left(\mu+\alpha+\gamma+u_{1}+u_{2}\right) \\
\Leftrightarrow \beta\left(\mu+u_{2}\right) & <\frac{\left(\mu+u_{1}+u_{2}\right)(\mu+\alpha+\gamma)\left(\mu+\alpha+\gamma+u_{1}+u_{2}\right)}{\left(\mu+\alpha+\gamma+u_{2}\right)} \\
& <\frac{\left(\mu+u_{1}+u_{2}\right)(\mu+\alpha+\gamma)\left(\mu+\alpha+\gamma+u_{1}+u_{2}\right)}{(\mu+\alpha+\gamma)}
\end{aligned}
$$




$$
\Leftrightarrow \beta\left(\mu+u_{2}\right)<\left(\mu+u_{1}+u_{2}\right)\left(\mu+\alpha+\gamma+u_{1}+u_{2}\right)
$$

Diperhatikan pembilang dari $a_{1}$

$$
\begin{aligned}
& \left(2 \mu+u_{1}+u_{2}+2 \alpha+2 \gamma\right)\left(\mu+u_{1}+u_{2}\right)-\beta\left(\mu+u_{2}\right) \\
= & \left((\mu+\alpha+\gamma)+\left(\mu+\alpha+\gamma+u_{1}+u_{2}\right)\right)\left(\mu+u_{1}+u_{2}\right)-\beta\left(\mu+u_{2}\right) \\
> & \left(\mu+u_{1}+u_{2}\right)\left(\mu+\alpha+\gamma+u_{1}+u_{2}\right)-\beta\left(\mu+u_{2}\right) .
\end{aligned}
$$

Berdasarkan pers. (11),

$$
\left(\mu+u_{1}+u_{2}\right)\left(\mu+\alpha+\gamma+u_{1}+u_{2}\right)>\beta\left(\mu+u_{2}\right)
$$

maka

$$
\left(2 \mu+u_{1}+u_{2}+2 \alpha+2 \gamma\right)\left(\mu+u_{1}+u_{2}\right)-\beta\left(\mu+u_{2}\right)>0 .
$$

Terbukti pembilang dari $a_{1}$ positif dan jelas bahwa penyebut dari $a_{1}$ juga positif maka $a_{1}>0$.

Diperhatikan bahwa

$$
\begin{aligned}
a_{2} & =m\left(\mu+u_{2}+\alpha+\gamma\right)-u_{1} u_{2} \\
& =\left(\left(\mu+u_{1}+\alpha+\gamma\right)-\beta\left(\frac{\mu+u_{2}}{\mu+u_{1}+u_{2}}\right)\right)\left(\mu+u_{2}+\alpha+\gamma\right)-u_{1} u_{2} \\
& =\frac{\left(\left(\mu+u_{1}+\alpha+\gamma\right)\left(\mu+u_{1}+u_{2}\right)-\beta\left(\mu+u_{2}\right)\right)\left(\mu+u_{2}+\alpha+\gamma\right)-u_{1} u_{2}\left(\mu+u_{1}+u_{2}\right)}{\mu+u_{1}+u_{2}}
\end{aligned}
$$

sehingga pembilang dari $a_{2}$ adalah

$$
\begin{aligned}
& \left((\mu+\alpha+\gamma)\left(\mu+u_{1}+u_{2}\right)+u_{1}\left(\mu+u_{1}+u_{2}\right)-\beta\left(\mu+u_{2}\right)\right)\left(\mu+u_{2}+\alpha+\gamma\right)-u_{1} u_{2}\left(\mu+u_{1}+u_{2}\right) \\
= & \left((\mu+\alpha+\gamma)\left(\mu+u_{1}+u_{2}\right)-\beta\left(\mu+u_{2}\right)\right)\left(\mu+u_{2}+\alpha+\gamma\right)+u_{1}\left(\mu+u_{1}+u_{2}\right)\left(\mu+u_{2}+\alpha+\gamma\right) \\
& -u_{1} u_{2}\left(\mu+u_{1}+u_{2}\right) \\
= & \left((\mu+\alpha+\gamma)\left(\mu+u_{1}+u_{2}\right)-\beta\left(\mu+u_{2}\right)\right)\left(\mu+u_{2}+\alpha+\gamma\right)+u_{1}\left(\mu+u_{1}+u_{2}\right)(\mu+\alpha+\gamma) \\
& +u_{1} u_{2}\left(\mu+u_{1}+u_{2}\right)-u_{1} u_{2}\left(\mu+u_{1}+u_{2}\right) \\
= & \left((\mu+\alpha+\gamma)\left(\mu+u_{1}+u_{2}\right)-\beta\left(\mu+u_{2}\right)\right)\left(\mu+u_{2}+\alpha+\gamma\right)+u_{1}\left(\mu+u_{1}+u_{2}\right)(\mu+\alpha+\gamma) \\
= & (\mu+\alpha+\gamma)\left(\mu+u_{1}+u_{2}\right)\left(\mu+u_{2}+\alpha+\gamma\right)+u_{1}\left(\mu+u_{1}+u_{2}\right)(\mu+\alpha+\gamma)-\beta\left(\mu+u_{2}\right)\left(\mu+u_{2}+\alpha+\gamma\right) \\
= & (\mu+\alpha+\gamma)\left(\mu+u_{1}+u_{2}\right)\left(\alpha+\gamma+\mu+u_{1}+u_{2}\right)-\beta\left(\mu+u_{2}\right)\left(\mu+u_{2}+\alpha+\gamma\right) .
\end{aligned}
$$

Berdasarkan pers. (10),

$$
\left(\mu+u_{1}+u_{2}\right)(\mu+\alpha+\gamma)\left(\mu+\alpha+\gamma+u_{1}+u_{2}\right)>\beta\left(\mu+u_{2}\right)\left(\mu+\alpha+\gamma+u_{2}\right)
$$

maka

$$
(\mu+\alpha+\gamma)\left(\mu+u_{1}+u_{2}\right)\left(\alpha+\gamma+\mu+u_{1}+u_{2}\right)-\beta\left(\mu+u_{2}\right)\left(\mu+u_{2}+\alpha+\gamma\right)>0 .
$$

Terbukti pembilang dari $a_{2}$ positif dan jelas bahwa penyebut dari $a_{2}$ juga positif maka $a_{2}>0$.

Selanjutnya matriks Routh Hurwitz $\Delta_{1}=a_{1}>0$ dan $\Delta_{2}=\left|\begin{array}{cc}a_{1} & a_{0} \\ 0 & a_{2}\end{array}\right|=a_{1} a_{2}$ karena $a_{1}>0$ dan $a_{2}>0$ maka $\Delta_{2}$ sehingga dapat disimpulkan polinomial $Q$ memenuhi kriteria Routh Hurwitz, maka bagian real akar-akar polinomial $Q$ bernilai negatif atau dapat dituliskan $\operatorname{Re}\left(\lambda_{4}\right)<0$ dan $\operatorname{Re}\left(\lambda_{5}\right)<0$. Dengan demikian semua akarakar persamaan karakteristik untuk $J_{\left(E_{1}\right)}$ bagian realnya negatif. Sehingga berdasarkan teorema pada [25] dapat disimpulkan bahwa titik ekulibrium bebas penyakit $E_{1}=\left(\frac{\mu+u_{2}}{\mu+u_{1}+u_{2}}, \frac{u_{1}}{\mu+u_{1}+u_{2}}, 0,0,0\right)$ stabil asimtotik lokal jika $R_{0}<1$.

\subsection{Simulasi Numerik}

Simulasi model dilakukan untuk memberikan gambaran geometris dari solusi dan untuk mendukung teorema yang diperoleh. Simulasi numerik model matematika penyebaran COVID-19 dengan penggunaan masker kesehatan dan karantina dengan mengambil nilai parameter dari beberapa penelitian. Secara sistematis nilai parameter dapat disajikan dalam bentuk tabel sebagai berikut. 
Tabel 3. Nilai-nilai parameter

\begin{tabular}{cccc}
\hline Parameter & Nilai & Satuan & Referensi \\
\hline$\mu$ & 0,0125 & perhari & {$[26]$} \\
$\beta$ & 0,2 & perindividu perhari & {$[27]$} \\
$u_{1}$ & 0,6 & perhari & Asumsi \\
$u_{2}$ & 0,4 & perhari & Asumsi \\
$\alpha$ & 0,084 & perhari & {$[27]$} \\
$\theta$ & 0,155 & perhari & {$[28]$} \\
$\gamma$ & 0,025 & perhari & {$[28]$} \\
\hline
\end{tabular}

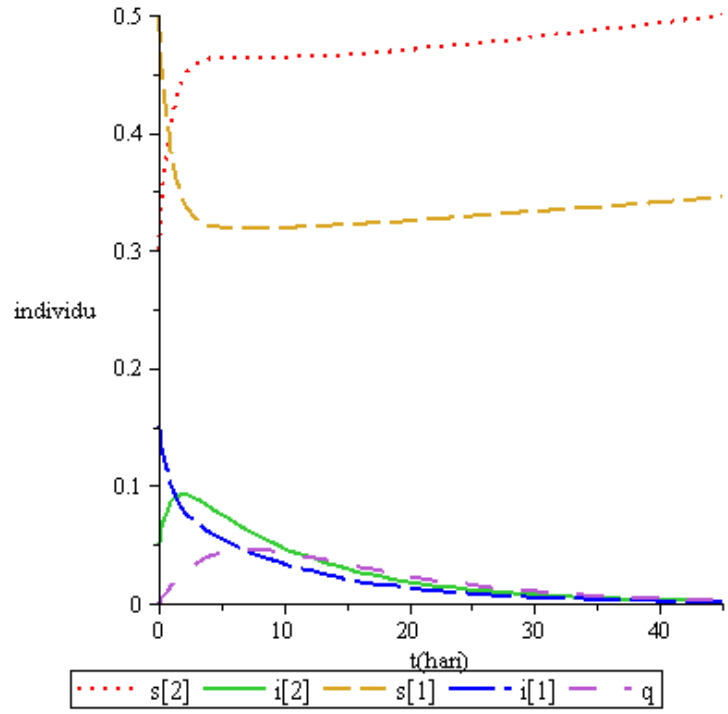

(a) $t=1-45$

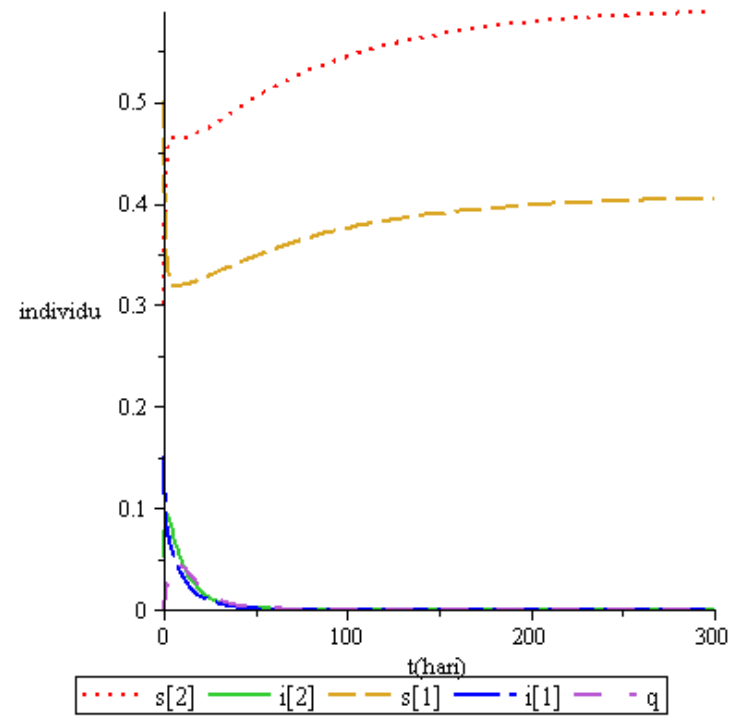

(b) $t=1-300$

Gambar 2. Simulasi sistem (2) menuju titik ekuilibrium bebas penyakit

Hasil simulasi menggunakan program Maplesoft Maple 20 dan berdasarkan parameter pada Tabel 3 serta dengan nilai awal $S_{1}(0)=0,5, S_{2}(0)=0,3, I_{1}(0)=0,15, I_{2}(0)=0,05, Q(0)=0,0$ diperoleh $R_{0}=0,413724723$ dan disajikan dalam gambar berikut.

Berdasarkan Gambar 2 dapat dilihat populasi individu rentan tidak menggunakan masker kesehatan $\left(S_{1}\right)$ dan populasi individu rentan menggunakan masker kesehatan $\left(S_{2}\right)$ meningkat dari kondisi awal hingga hari ke-300, berturut-turut menuju titik 0,4074074074 dan 0,5925925926 serta stabil di titik tersebut. Populasi individu terinfeksi tidak menggunakan masker kesehatan $\left(I_{1}\right)$ turun hingga hari ke-45 menuju titik 0 dan stabil di titik tersebut. Populasi individu terinfeksi menggunakna masker kesehatan $\left(I_{2}\right)$ dan populasi individu yang dikarantina $(Q)$ awalnya meningkat tetapi setelah itu menurun menuju titik kestabilan 0 pada hari ke-45. Kesimpulan yang diperoleh dari simulasi yang pertama ini adalah penyakit akan menghilang dari populasi setelah hari ke-45 jika $R_{0}<1$, hasil ini sesuai dengan teorema 2 yang telah dibentuk sebelumnya.

Selanjutnya akan dilakukan simulasi numerik titik ekuilibrium endemik $E_{2}$ untuk $R_{0}>1$. Nilai parameter yang digunakan sama dengan simulasi $E_{1}$ kecuali parameter pelepasan masker $u_{2}$ diperbesar menajadi $u_{2}=0,85$ dan parameter penggunaan masker $u_{1}$ diperkecil menjadi $u_{1}=0,15$ sehingga diperoleh bilangan reproduksi dasar $R_{0}=1,214678422$ serta digunakan nilai awal sama dengan $E_{1}$.

Berdasarkan Gambar 3 dapat dilihat populasi individu rentan tidak menggunakan masker kesehatan $\left(S_{1}\right)$ dan populasi individu rentan menggunakan masker kesehatan $\left(S_{2}\right)$ mengalami fluktuasi hingga stabil pada hari ke-650, berturut-turut menuju titik 0,7012982501 dan 0,1219649130. Populasi individu terinfeksi tidak menggunakan masker kesehatan $\left(I_{1}\right)$, populasi individu terinfeksi menggunakna masker kesehatan $\left(I_{2}\right)$ dan populasi individu yang dikarantina $(Q)$ awalnya menurun menuju nol tetapi setelah itu meningkat menuju titik kestabilan pada hari ke-300 berturut-turut di titik 0.001969871121; 0,0003041489122 dan 0,0009922996514. Kesimpulan yang diperoleh dari simulasi yang kedua ini adalah penyakit akan menetap pada populasi jika $R_{0}>1$. Hasil ini sesuai dengan teorema 1 bahwa jika $R_{0}>1$ akan muncul titik ekuilibrium endemik. 


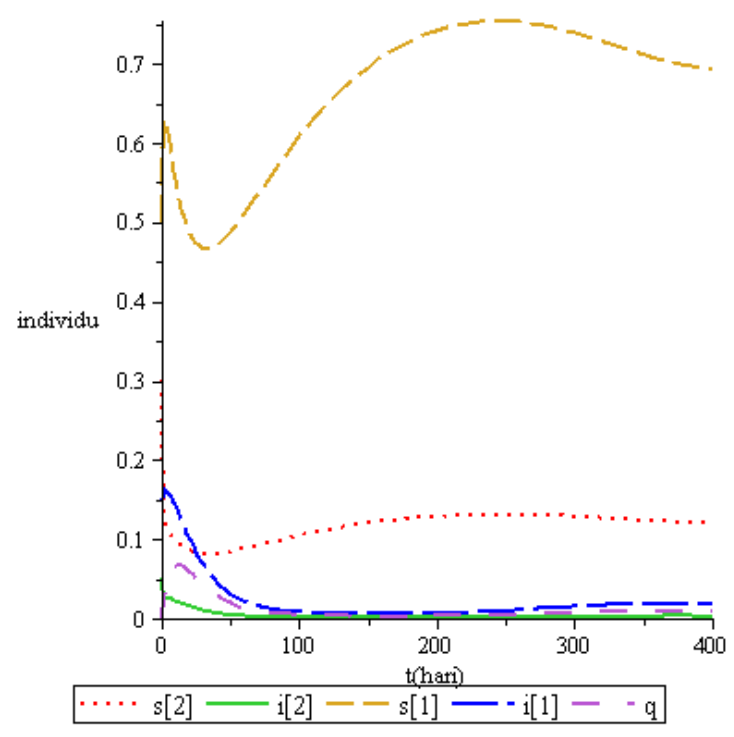

(a) $t=1-400$

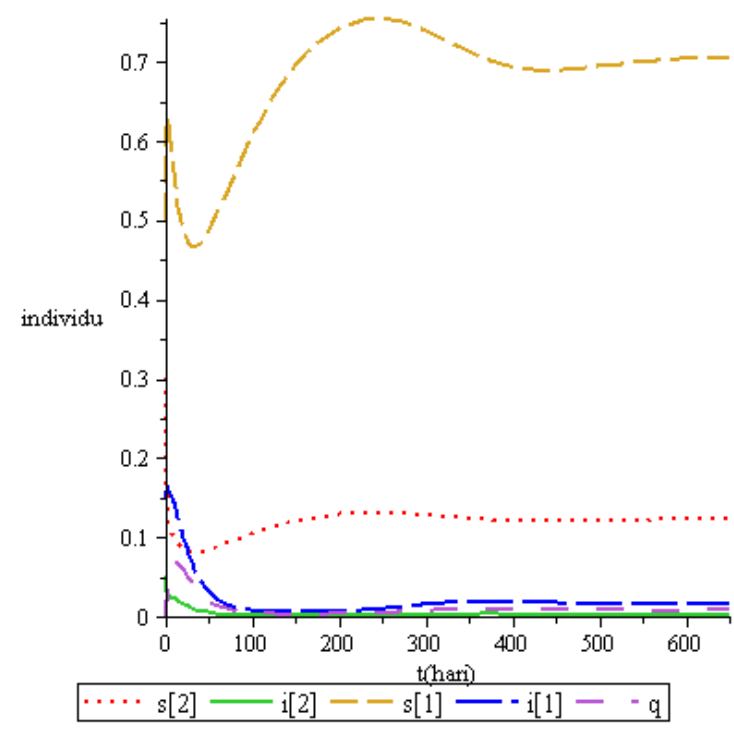

(b) $t=1-650$

Gambar 3. Simulasi sistem (2) titik ekuilibrium endemik

\subsection{Analisis Sensitifitas}

Analisis sensitivitas digunakan untuk mengidentifikasi parameter yang memiliki pengaruh paling signifikan pada nilai $R_{0}$. Parameter yang berpengaruh signifikan pada $R_{0}$ menunjukkan bahwa parameter tersebut memiliki pengaruh yang paling dominan terhadap epidemi atau penyebaran COVID-19. Analisis sensitivitas dalam penelitian ini merujuk pada penelitian $[29,30]$ yang selanjutnya diaplikasikan pada nilai parameter Tabel 4. Sebagai contoh berikut disajikan perhitungan indeks sensitivitas $R_{0}$ terhadap parameter $\beta$.

$$
\begin{aligned}
C_{\beta}^{R_{0}} & =\frac{\partial R_{0}}{\partial \beta} \times \frac{\beta}{R_{0}} \\
& =\frac{\left(\mu+u_{2}\right)\left(\mu+u_{2}+\alpha+\gamma\right)}{\left(\mu+u_{1}+u_{2}\right)(\mu+\alpha+\gamma)\left(\mu+u_{1}+u_{2}+\alpha+\gamma\right)} \times \frac{\beta\left(\mu+u_{1}+u_{2}\right)(\mu+\alpha+\gamma)\left(\mu+u_{1}+u_{2}+\alpha+\gamma\right)}{\left(\mu+u_{2}\right)\left(\mu+u_{2}+\alpha+\gamma\right)} \\
& =1
\end{aligned}
$$

Tabel 4. Indeks sensitivitas parameter

\begin{tabular}{lll}
\hline No & Parameter & Indeks Sensitifitas \\
\hline 1 & $\beta$ & 1 \\
2 & $u_{1}$ & $-0,9960381543$ \\
3 & $u_{2}$ & 0,8854041722 \\
4 & $\alpha$ & $-0,6242458782$ \\
5 & $\gamma$ & $-0,1857874637$ \\
6 & $\mu$ & $-0,07933267511$ \\
\hline
\end{tabular}

Indeks sensitivitas pada Tabel 4 secara berurutan menunjukkan parameter dengan indeks sensitivitas tertinggi ke terendah. Sehingga dapat disimpulkan empat parameter yang berpengaruh signifikan terhadap persebaran penyakit yaitu berturut-turut tingkat kontak individu rentan dengan terinfeksi $(\beta)$, tingkat penggunaan masker kesehatan $\left(u_{1}\right)$, tingkat pelepasan masker kesehatan $\left(u_{2}\right)$, dan tingkat individu yang dikarantina $(\alpha)$. Terdapat dua parameter indeks sensitivitasnya positif yakni $\beta$ dan $u_{2}$, hal ini bermakna jika nilai parameter tersebut meningkat maka persebaran COVID-19 juga akan meningkat dan sebaliknya. Selanjutnya ada empat parameter dengan indeks sensitifitasnya negatif yakni $u_{1}, \alpha, \gamma$, dan $\mu$, hal ini artinya dengan meningkatkan nilai parameter tersebut akan berpengaruh terhadap menurunya persebaran COVID-19 dan sebaliknya.

Makna dari indeks sensitivitas $\beta$ sebesar 1 adalah ketika parameter $\beta$ diperbesar (atau diperkecil) sebesar misal $10 \%$ dan parameter lainnya tetap maka nilai $R_{0}$ akan meningkat (atau menurun) sebesar $10 \%$. Indeks sensitivitas $u_{1}$ sebesar -0,9960381543 memiliki makna ketika parameter $\alpha$ diperbesar (atau diperkecil) missal sebesar 10\% dan parameter lainnya tetap maka nilai $R_{0}$ akan menurun (atau meningkat) sebesar $9,96 \%$. 
Berdasarkan hasil analisis model dan simulasi numerik dapat disimpulkan penyakit ini akan menjadi mewabah apabila $R_{0}>1$. Tindakan selanjutnya untuk mencegah terjadinya wabah dapat dilakukan dengan cara membuat nilai $R_{0}<1$ yaitu dengan cara sebagai berikut:

1. Mengurangi kontak individu rentan dengan individu terinfeksi, misalkan dengan menghindari kerumunan dan menjaga jarak.

2. Mengurangi laju pelepasan masker kesehatan dan meningkatkan laju penggunaan masker kesehatan baik pada individu rentan ataupun terinfeksi. Pemerintah dapat mensosialisasikan kembali pentingnya penggunaan masker sebagai upaya pencegahan penularan COVID-19.

3. Meningkatkan laju karantina bagi individu terinfeksi COVID-19 baik mandiri ataupun dirumah sakit bagi individu yang terinfeksi.

\section{Kesimpulan}

Berdasarkan asumsi-asumsi yang telah ditetapkan pada penelitian ini, dapat disimpulkan diperoleh model matematika penyebaran COVID-19 dengan penggunaan masker kesehatan dan karantina. Model yang diperoleh berupa sistem persamaan differensial linear non linear. Dari model tersebut diperoleh dua titik ekuilibrum yaitu titik ekuilibrium bebas penyakit dan titik ekuilibrium endemik. Titik ekuilibrium bebas penyakit memiliki kestabilan titik ekuilibrium stabil asimtotik tokal saat $R_{0}<1$ dan titik ekuilibrium endemik ada jika $R_{0}>1$. Simulasi numerik model mendukung hasil analisis yang diperoleh. Terakhir analisis sensitivitas bilangan reproduksi dasar yang dilakukan diperoleh empat parameter yang dominan berpengaruh terhadap bilangan reproduksi dasar yakni berturut-turut dari yang paling berpengaruh, tingkat kontak individu rentan dengan terinfeksi, tingkat penggunaan masker kesehatan, tingkat pelepasan masker kesehatan, dan tingkat individu yang dikarantina.

\section{Ucapan Terimakasih}

Terima kasih kepada Program Studi Matematika, Fakultas Sains dan Teknologi, UIN Syarif Hidayatullah Jakarta yang telah memberikan dukungan penelitian ini.

\section{Referensi}

[1] D. Handayani, D. R. Hadi, F. Isbaniah, E. Burhan, dan H. Agustin, "Corona virus disease 2019," Jurnal Respirologi Indonesia, vol. 40, no. 2, hal. 119-129, 2020.

[2] Fathiyah Isbaniah dan Agus Dwi Susanto, "Pneumonia corona virus infection disease-19 (COVID-19)," Journal Of The Indonesian Medical Association, vol. 70, no. 4, hal. 87-94, 2020.

[3] M. Manaqib, I. Fauziah, dan M. Mujiyanti, "Mathematical model for MERS-COV disease transmission with medical mask usage and vaccination," InPrime: Indonesian Journal of Pure and Applied Mathematics, vol. 1, no. 2, 2019.

[4] Y. Yuliana, "Corona virus diseases (Covid-19): Sebuah tinjauan literatur," Wellness And Healthy Magazine, vol. 2, no. 1, hal. 187-192, 2020.

[5] C.-C. Lai, S.-Y. Chen, M.-Y. Yen, P.-I. Lee, W.-C. Ko, dan P.-R. Hsueh, “The impact of COVID-19 preventative measures on airborne/droplet-transmitted infectious diseases in Taiwan," Journal of Infection, vol. 82, no. 3, hal. e30-e31, 2021.

[6] M. Jayaweera, H. Perera, B. Gunawardana, dan J. Manatunge, "Transmission of COVID-19 virus by droplets and aerosols: A critical review on the unresolved dichotomy," Environmental Research, vol. 188, no. June, hal. 109819, 2020.

[7] P. Anfinrud, V. Stadnytskyi, C. E. Bax, dan A. Bax, "Visualizing speech-generated oral fluid droplets with laser light scattering," New England Journal of Medicine, vol. 382, no. 21, hal. 2061-2063, 2020.

[8] M. Ali, S. T. H. Shah, M. Imran, dan A. Khan, "The role of asymptomatic class, quarantine and isolation in the transmission of COVID-19," Journal of Biological Dynamics, vol. 14, no. 1, hal. 389-408, 2020.

[9] WHO, “WHO director-general's opening remarks." 2020.

[10] Komite Pengendalian Covid-19 dan Pemulihan Ekonomi Nasional (KPC PEN), "Peta Sebaran COVID-19."

[11] _ _ "Lakukan Semua: 3M, 3T, dan Vaksinasi."

[12] I. Taufiq dan D. Agustito, "Application of mathematical models two predators and infected prey by pesticide control in Nilaparvata Lugens spreading in Bantul regency," InPrime: Indonesian Journal of Pure and Applied Mathematics, vol. 2, no. 1, hal. 41-50, 2020.

[13] W. O. Kermack dan A. G. McKendrick, "A contribution to the mathematical theory of epidemics," Proceedings of the Royal Society of London. Series A, Containing Papers of a Mathematical and Physical Character, vol. 115, no. 772, hal. 700-721, 1927.

[14] G. O. Fosu, J. M. Opong, dan J. K. Appati, "Construction of compartmental models for COVID-19 with quarantine, lockdown and vaccine interventions," SSRN Electronic Journal, hal. 1-15, 2020.

[15] M. Imran, M. Wu, Y. Zhao, E. Beşe, dan M. J. Khan, "Mathematical modelling of SIR for COVID-19 forecasting," Revista Argentina de Clinica Psicologica, vol. 30, no. 1, hal. 218-226, 2021. 
[16] M. Ivanova dan L. Dospatliev, “Data analytics and SIR modeling of COVID-19 in Bulgaria," International Journal of Apllied Mathematics, vol. 33, no. 6, 2021.

[17] Z. Liao, P. Lan, Z. Liao, Y. Zhang, dan S. Liu, "TW-SIR: time-window based SIR for COVID-19 forecasts," Scientific Reports, vol. 10, no. 1, hal. 22454, 2020.

[18] A. Mitra, "COVID-19 in India and SIR model," Journal of Mechanics of Continua and Mathematical Sciences, vol. 15, no. 7, 2020.

[19] M. Amaku, D. T. Covas, F. A. Bezerra Coutinho, R. S. Azevedo Neto, C. Struchiner, A. Wilder-Smith, dan E. Massad, "Modelling the test, trace and quarantine strategy to control the COVID-19 epidemic in the state of São Paulo, Brazil," Infectious Disease Modelling, vol. 6, hal. 46-55, 2021.

[20] M. Chinazzi, J. T. Davis, M. Ajelli, C. Gioannini, M. Litvinova, S. Merler, A. Pastore y Piontti, K. Mu, L. Rossi, K. Sun, C. Viboud, X. Xiong, H. Yu, M. E. Halloran, I. M. Longini, dan A. Vespignani, "The effect of travel restrictions on the spread of the 2019 novel coronavirus (COVID-19) outbreak," Science, vol. 368, no. 6489, hal. 395-400, 2020.

[21] B. Tang, F. Xia, S. Tang, N. L. Bragazzi, Q. Li, X. Sun, J. Liang, Y. Xiao, dan J. Wu, "The effectiveness of quarantine and isolation determine the trend of the COVID-19 epidemics in the final phase of the current outbreak in China," International Journal of Infectious Diseases, vol. 95, hal. 288-293, 2020.

[22] Y. Xiang, Y. Jia, L. Chen, L. Guo, B. Shu, dan E. Long, "COVID-19 epidemic prediction and the impact of public health interventions: A review of COVID-19 epidemic models," Infectious Disease Modelling, vol. 6, no. 24, hal. 324-342, 2021.

[23] D. Aldila, H. Padma, K. Khotimah, B. Desjwiandra, dan H. Tasman, "Analyzing the MERS disease control strategy through an optimal control problem," International Journal of Applied Mathematics and Computer Science, vol. 28, no. 1, hal. 169-184, 2018.

[24] N. Inayah, M. Manaqib, N. Fitriyati, dan I. Yupinto, "Model matematika dari penyebaran penyakit Pulmonary Tuberculosis dengan penggunaan masker medis," BAREKENG: Jurnal Ilmu Matematika dan Terapan, vol. 14, no. 3, hal. 461-472, 2020.

[25] S. Wiggins, Introduction to applied nonlinear dynamical systems and chaos, 2nd ed. New York: Springer, 2003.

[26] Badan Pusat Statistik, "Hasil Sensus Penduduk 2020," 2020.

[27] B. K. Mishra, A. K. Keshri, Y. S. Rao, B. K. Mishra, B. Mahato, S. Ayesha, B. P. Rukhaiyyar, D. K. Saini, dan A. K. Singh, "COVID-19 created chaos across the globe: Three novel quarantine epidemic models," Chaos, Solitons E Fractals, vol. 138, hal. 109928, 2020.

[28] S. S. Musa, S. Qureshi, S. Zhao, A. Yusuf, U. T. Mustapha, dan D. He, "Mathematical modeling of COVID-19 epidemic with effect of awareness programs," Infectious Disease Modelling, vol. 6, hal. 448-460, 2021.

[29] N. Chitnis, J. M. Hyman, dan J. M. Cushing, "Determining important parameters in the spread of Malaria through the sensitivity analysis of a mathematical model," Bulletin of Mathematical Biology, vol. 70, no. 5, hal. 1272-1296, 2008.

[30] R. Resmawan dan L. Yahya, "Sensitifity analysis of mathematical model of Coronavirus Disease (COVID-19) transmission," CAUCHY, vol. 6, no. 2, hal. 91, 2020.

C2021 by the Author(s). This article is an open access article distributed under the terms and conditions of the Creative Commons Attribution-NonComercial 4.0 International License. Editorial of JJBM: Department of Mathematics, State University of Gorontalo, Jln. Prof. Dr. Ing. B. J. Habibie, Bone Bolango 96119, Indonesia. 


\section{Submit your manuscript at http://ejurnal.ung.ac.id/}

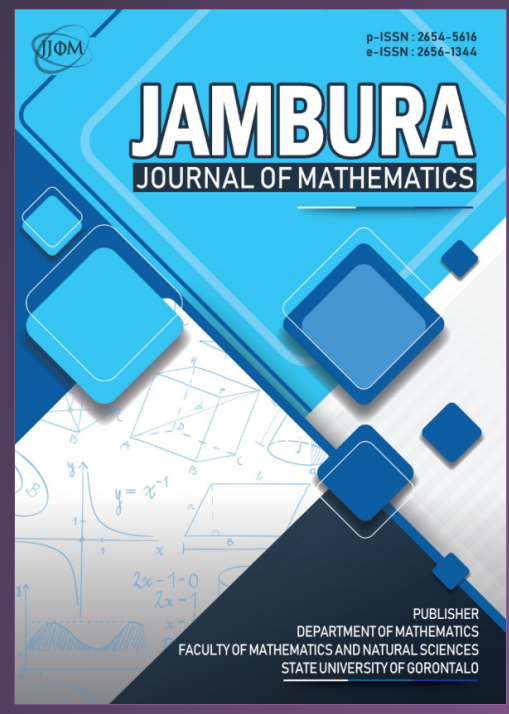

Jambura Journal of Mathematics

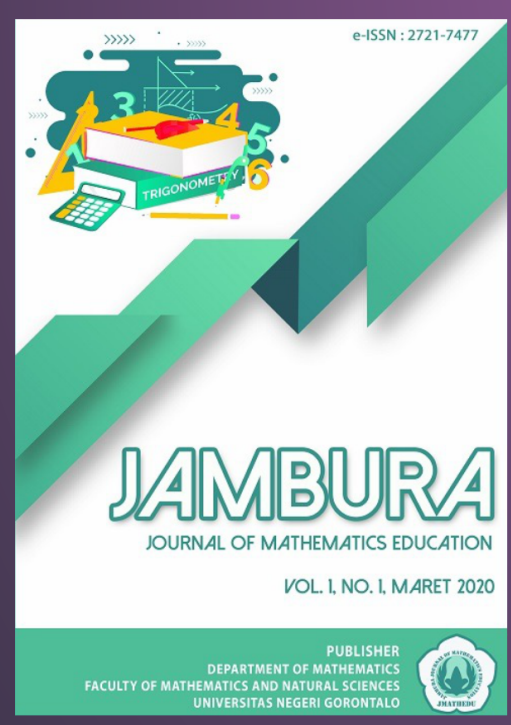

Jambura Journal of Mathematics Education
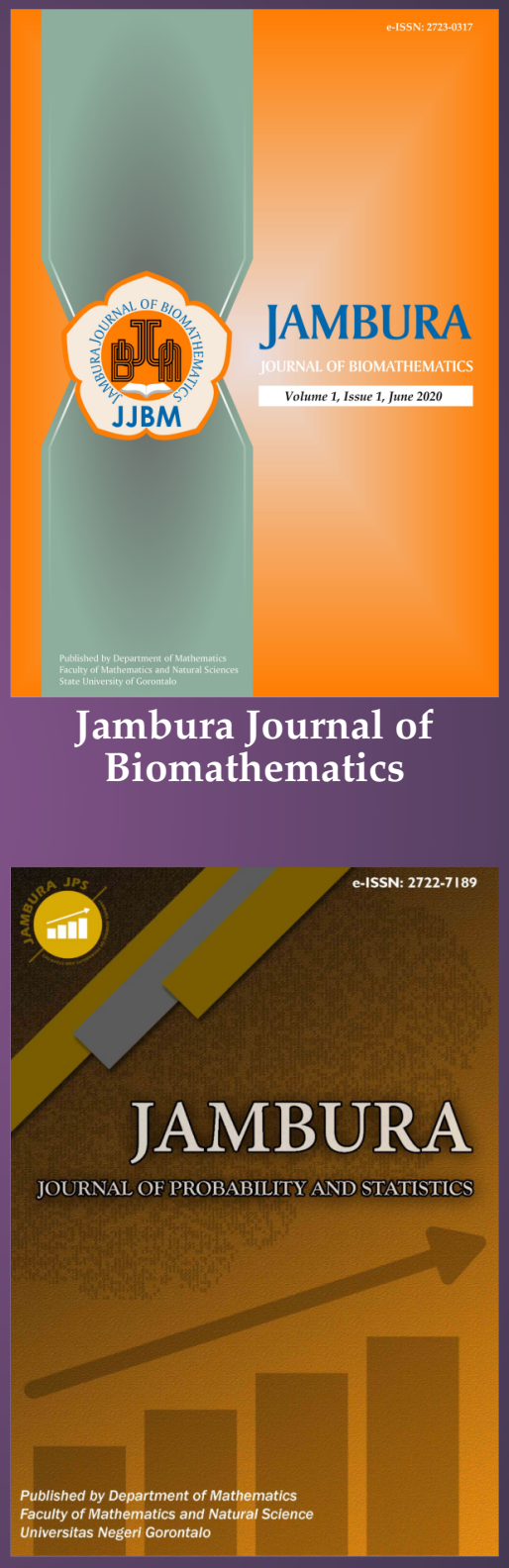

Jambura Journal of Probability and Statistics

Published by

Department of Mathematics

Faculty of Mathematics and Natural Sciences

State University of Gorontalo 